PERM JOURNAL OF PETROLEUM AND MINING ENGINEERING

ВЕСТНИК ПНИПУ. ГЕОЛОГИЯ. НЕФТЕГАЗОВОЕ И ГОРНОЕ ДЕЛО

ISSN 2224-9923

Volume / Tом 17 №2 2018

http://vestnik:pstu.ru/geo/

УДК 622.276:665.61.033.28

Article / Статья

(C) PNRPU / ПНИПУ, 2018

\title{
EFFECT OF FRACTAL DIMENSION OF ASPHALTEN AGGREGATES ON MACRO PROPERTIES OF NATIVE OIL
}

\author{
Aleksandr A. Zlobin \\ Perm National Research Polytechnic University (29 Komsomolskiy av., Perm, 614990, Russian Federation)

\section{ВЛИЯНИЕ ФРАКТАЛЬНОЙ РАЗМЕРНОСТИ АСФАЛЬТЕНОВЫХ АГРЕГАТОВ НА МАКРОСВОЙСТВА НАТИВНОЙ НЕФТИ}

\section{А.А. Злобин}

Пермский национальный исследовательский политехнический университет (614990, Россия, г. Пермь, Комсомольский пр., 29)

Received / Получена: 07.02.2018. Accepted / Принята: 09.06.2018. Published / Опубликована: 29.06.2018

\section{Key words:}

dimensions of asphaltenic core, structure of complex structural units, fractal dimension of nucleus, temperature aggregation of asphaltenes, effectiveness of wax inhibitors.

\begin{abstract}
The paper discusses the complex analysis of the energy and structural features of the structure of asphaltenes of nanoaggregates that was experimentally conducted using the data of the nuclear magnetic resonance method. Fractal dimension of the core of complex structural units (CSU) for two alternative groups of native oil was calculated, which is equal to 2.040 and 1.556 units. It is established that crude oils with a low fractal dimension of nucleus have a 1.5-5.0 times higher dynamic viscosity. Theoretical substantiation of the physical phenomenon was carried out. It is established that oils of low fractal dimension due to their structural individuality of the structure of the paramagnetic framework have an increased natural inhibitory capacity of the asphaltenes of the nucleus in relation to growth and fallout of solid paraffins forming organic was depostion. According to temperature studies simulating cooling of the flow of oil during lifting in the tubing, it was established that the growth of the radius of the CSU nucleus during aggregation of asphaltenes is well described by the linear model. The aggregation intensity is 3.6 times higher in oil with more than low fractal dimension. In addition, it was revealed that the coefficient of temperature aggregation of asphaltenes depends on the radius of the initial material, and for the oil with a high fractal dimension it is described by a monotonous logarithmic model. There was an abnormal nonlinear aggregation established for low-dimensional oil at small radii of the initial material, which leads to a violation of the monotonic nature of the change in the coefficient of aggregation. According to results of experiments that simulate the deposition of paraffins on a metal surface, it has been established that the effectiveness of wax inhibitors in oil with a low fractal dimension is 5-49\% higher compared to a group of high-dimensional oil. The results obtained in the work can be used in practice when developing modern methods of managing the properties of petroleum dispersed systems in the development, production and processing of hydrocarbons.
\end{abstract}

В представленной работе с использованием данных метода ядерно-магнитного резонанса экспериментально проведен комплексный анализ энергетических и структурных особенностей строения асфальтеновых наноагрегатов и рассчитана фрактальная размерность ядра сложных структурных единиц (ССЕ) для двух альтернативных групп нативной нефти, которая составляет 2,040 и 1,556 ед. Установлено, что нефть с низкой фрактальной размерностью ядра обладает более высокой (в 1,5-5,0 раз) динамической вязкостью, и проведено теоретическое обоснование данного физического явления. Выявлено, что нефть с низкой фрактальной размерностью в силу своей структурной индивидуальности строения парамагнитного каркаса обладает повышенной естественной ингибирующей способностью асфальтенов ядра по отношению к росту и выпадению твердых парафинов, формирующих органические асфальтеносмолопарафиновые отложения (АСПО). По данным температурных исследований, моделирующих охлаждение потока нефти при подъеме в насосно-компрессорных трубах, установлено, что динамика роста радиуса ядра ССЕ при агрегации асфальтеновых частиц хорошо описывается линейной моделью, при этом интенсивность агрегации выше в среднем в 3,6 раза в нефти с более низкой фрактальной размерностью Дополнительно выявлено, что коэффициент температурной агрегации асфальтенов зависит от радиуса начальной затравки и для нефти с высокой фрактальной размерностью описывается монотонной логарифмической моделью. Для нефти с низкой размерностью установлена аномальная нелинейная агрегация при малых радиусах начальной затравки, что приводит к нарушению монотонного характера изменения коэффициента агрегации. По результатам опытов, моделирующих осаждение парафинов на металлической поверхности, установлено, что эффективность действия ингибиторов АСПО в нефти с низкой фрактальной размерностью на 5-49\% выше по сравнению с группой высокоразмерной нефти. Полученные в работе результаты могут быть использованы на практике при создании современных методов управления свойствами нефтяных дисперсных систем при разработке, добыче и переработке углеводородов.

Aleksandr A. Zlobin (Author ID in Scopus: 36712914500) - PhD in Engineering, Associate Professor at the Department of Oil and Gas Technologies (tel.: +007 919457 05 38, e-mail: ZlobinAA55@gmail.com).

Злобин Александр Аркадьевич - кандидат технических наук, доцент кафедры нефтегазовых технологий (тел.: +007 919 457 05 38, e-mail: ZlobinAA55@gmail.com). 


\section{Introduction}

Development and implementation of modern nanotechnologies is one of the priority areas for increasing the efficiency of recovery technologies and processing of crude hydrocarbon.

Today, there is no uniform standard that could describe what the nanotechnologies and nano goods are. On the territory of the Russian Federation the meaning of nanotechnology is established in GOST R 55416-2013 [1] (identical to the international document ISO/TS 80004-1: 2010 [2]) "Nanotechnology. Part 1. Basic terms and definitions", in particular: a set of technological methods used to study, design and manufacture materials, devices and systems, including control and management of the structure, chemical composition and interaction of constituent elements of the nanoscale on purpose. The practical aspect of nanotechnologies includes production of devices and their components necessary for creation, processing and manipulation of atoms, molecules and nanoparticles. In a broader sense, this term also covers methods of diagnostics, characterology, and studies of such nanoobjects.

One of the most important theoretical and practical questions facing nanotechnology today is how to get molecules to group themselves in a certain way, to organize themselves and eventually obtain materials and objects with new physical and chemical properties [3]. That opens up opportunities for more efficient management of properties of dispersed systems (oil, emulsions, drilling muds, surfactants, lubricating oils, additives etc.) in various oil and gas production processes [4-6], which makes nanotechnologies to be relevant.

In a series of previous works the author developed the method for determination the nanostructure of a complex structural unit (CSU) of oil using the nuclear magnetic resonance (NMR) method [7]. Aggregation and self-assembly processes of nanoparticles were studied [8, 9]; fractal dimension of the asphaltene core [10] of native oil was estimated. Results of studies are tested in practice to select the inhibitors of paraffin deposits [11] and develop the methods for preventing asphaltene, resin and paraffin deposition (ARPD) in production wells [12].
In the present paper that continues the cycle of works on nanoobjects a complex analysis of two groups of native oil was carried out. The groups differ in the magnitude of the fractal dimension of asphaltene aggregates. The effect of fractal dimension on various technological macroproperties of produced hydrocarbons is studied as well.

\section{Aggregation processes and fractal dimension of asphaltene complexes}

For the moment, physical and chemical properties, phase states of asphaltene aggregates and their dependence on the critical parameters of the system are quite well known. Nevertheless, it is emphasized that "current knowledge is sufficient for forecasting, but still insufficient to control the phase behavior of asphaltenes and oil systems as a whole" $[13,14]$.

Processes of self-organization of disperse systems in the general case are rather complicated and not completely understood. Thus, in a theory of water disperse systems the main role in aggregation is played by the charge Coulomb interactions of particles and potentials of charged interphase surfaces, which are well described by the DeryaginLandau-Fervey-Overbeck theory [15-17].

Everything is much more complicated in oleodispersed systems. Firstly, there are no Coulomb forces there. Secondly, the basic van der Waals interactions (orientational, induction and dispersion) have specific quantum properties and depend on the ratio of polar and nonpolar molecules. Thirdly, particles of a dispersed phase, that are also called complex structural units, surrounded by molecules of the dispersion medium, have a complex composition of structural elements such as a core, outer and inner solvate shells (Fig. 1), which can be transformed and cardinally rearranged under external impact of physical and chemical fields. For example, under the influence of temperature asphaltene core and solvate shell continuously change dimensions; in each oil it happens according to its own law [11]. An increase in radius of a CSU complex characterizes the aggregation process; decrease characterizes the peptization of particles.

Processes of aggregation of supramolecular asphaltene structures consist in convergence due to Brownian motion and collision of individual active 
complexes, which leads to the formation of a larger asphaltene core and CSU as a whole. In turn, peptization processes, inverse aggregations, consist in the spontaneous thermodynamically favorable dispersal (fragmentation) of a nucleus and appearance of a large number of smaller complexes of CSU. Any disperse system, which includes oil, tends to get a dynamic equilibrium between aggregation and peptization processes, which causes the kinetic stability of the nanostructure of aggregates under the influence of the temperature factor $K T$ ( $T$ - temperature, $K$ - constant L.E. Boltzmann).

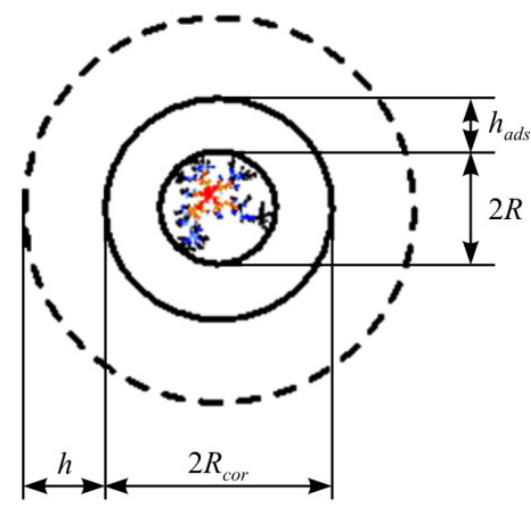

Fig. 1. Spherical model of complex structural unit of oil dispersed system: $R_{c o r}$ - radius of CSU; $R$ - radius of the asphaltene fractal core; $h$ - thickness of the outer solvate layer of solvent molecules; $h_{a d s}-$ thickness of internal adsorption-solvate layer made of resins.

The fractal core is in the center

The state, structure of CSU and self-assembly processes of the asphaltene core are determined theoretically by energy balance of intermolecular interactions between the dispersion medium and dispersed phase $[18,19]$, taking into account the permeability of the solvate shell made of resins. It was established in [8] that in case of oleodispersed systems the relative activation energy can be used as a parameter for aggregation of asphaltenes in oil $X\left(E_{c}\right)=E_{c}^{V} / E_{c}^{S}$, that characterizes the resulting driving force in the selfassembly of CSU in oil. Using this approach, a graphical function of the aggregation of the CSU nucleus in native oil was constructed (Fig. 2), taking into account the real content of hydrocarbons and asphaltene and resin substances.

Data analysis shows that with a significant difference in energy of the dispersion medium and dispersed phase, size of nucleus on the left and right tends to an equilibrium state with a minimum radius of $10 \mathrm{~nm}$ (Fig. 2), which confirms the theory of extreme states of CSU [18]. Energy of the medium (solvent) and dispersed phase is the limiting condition for extreme metastable state of the nucleus, to which both branches of the graph tend but do not really reach it. The obtained "resonant" type of the graph in Fig. 2 is universal for both oleophobic and oleophilic systems, which is confirmed by the data of [20], where the mechanism of growth of particles of water metal sol. But $\mathrm{pH}$ value of the medium is a driving force of aggregation in [20], which regulates the potential of the electrostatic interaction of initial particles.

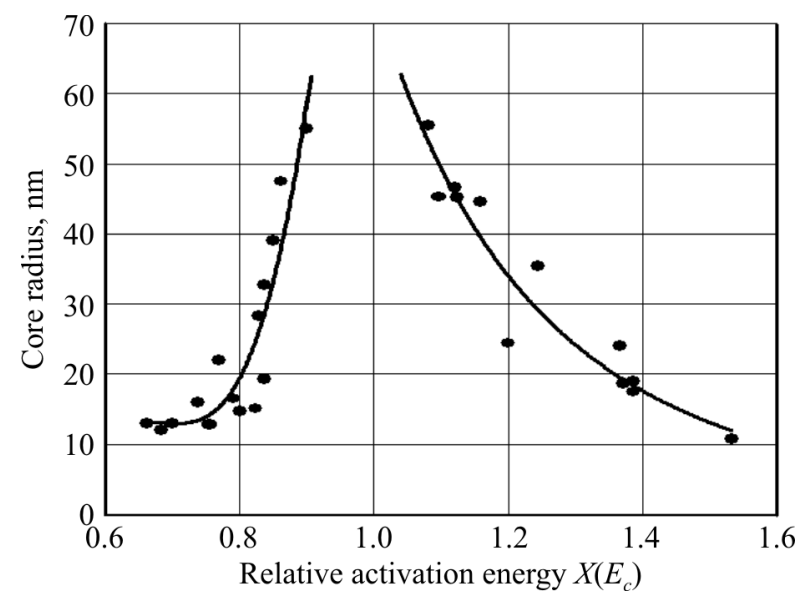

Fig. 2. Graph of dependence of the radius of the asphaltene core on aggregation parameter in native oil samples

The function of change of CSU nucleus size from the aggregation parameter for native oil in Fig. 2 consists of two branches such as left and right which characterize the different energy potential of a nucleus. The left branch describes the oil in which $X\left(E_{c}\right)<1$, i.e. the energy of a dispersion medium is less than energy at the interphase boundary with the nucleus. The right branch in Fig. 1 describes an oil group of condition $X\left(E_{c}\right)>1$ and, respectivelly, the energy of a dispersion medium is greater than the energy of a dispersed phase. In general, the kernel aggregation function in Fig. 2 is asymmetric, which indicates a significant difference between these two groups of oil. Using the analogy with aggregation in water colloids, we can presumably speak about existance in the oil of the fast mechanism [21] (left branch) and slow (right branch) aggregation of particles. 
It was established that aggregation of asphaltenes in native oil occurs according to two different scenarios that are caused by individual structural and energy properties of the CSU.

For the analysis oil with left-hand aggregation is referred to the first experimental group with a "strong core" and "weak core" for oil with righthand aggregation.

Strong nucleus is characterised by a step-bystep increase in the radius of the aggregate (see Fig. 2). Weak nucleus is characterised by smoothly and monotonously rearrangement over a wider range of aggregation parameter change $X\left(E_{c}\right)$ ( 0.45 vs. 0.25 fraction units).

The complex analysis carried out comparing the properties of two groups of oil that are not equivalent in terms of aggregation showed that for identical core radii, the following differences are observed. Average oil density in the first group is somewhat larger than in the second group. Average thickness of the solvate shell of resins in the first group is greater than in the second one by $32-35 \%$. The radius of the CSU complex in the first group is greater than in the second one by $18-20 \%$. The sulfur content in the first group is slightly higher than of the second group.

Regardless all features mentioned, different energy activity of the CSU nucleus is the main difference between the groups. That is clearly seen from the data of the experiment in Fig. 3, where, firstly, the average activation energy [22] at the boundary with the dispersed phase in the first group is higher than in the second one by $47.8 \%$ rel. (18.96 against $12.83 \mathrm{~kJ} / \mathrm{mol}$ ). Secondly, the change in the activation energy differs significantly in the groups. Thus, for the second group, increase in the nuclear radius is accompanied by an almost linear increase, and then a decrease in the activation energy after reaching an extreme size of $45 \mathrm{~nm}$.

There is a nonlinear (oscillation) character of the activation parameter observed caused by at least three extremal states separated by equidistant intervals of $10-12 \mathrm{~nm}$.

Thus, the first group has critical sizes of nucleus, under which self-consistent amplification or attenuation of the activation potential occurs. Such features do not appear in the second group or they are rather weak in magnitude.

Extremes of native oil observed in the graphs of Fig. 3 correspond to metastable states of conversion of the CSU structure with change in the content of the dispersed phase, which is confirmed by the data in Fig. 4 that shows the experimental graphs of the relationship between the thickness of the solvation shell and CSU radius. It is found that the thickness of the adsorption shell for the second group (chart 2) remains the same at $24 \pm 2 \mathrm{~nm}$ up to the boundary radius and then increases slightly, which characterizes a weak dependence of solvate shell thickness on nuclear radius. In other words, a core with low activity is surrounded by a relatively homogeneous thin solvate shell. Comparing the graphs in Fig. 3 and 4 it is clear that activation energy at the boundary with nucleus is negatively related to the ratio of solvate shell thickness to the radius of the nucleus $h_{a d s} / R$, i.e. core shielding factor.

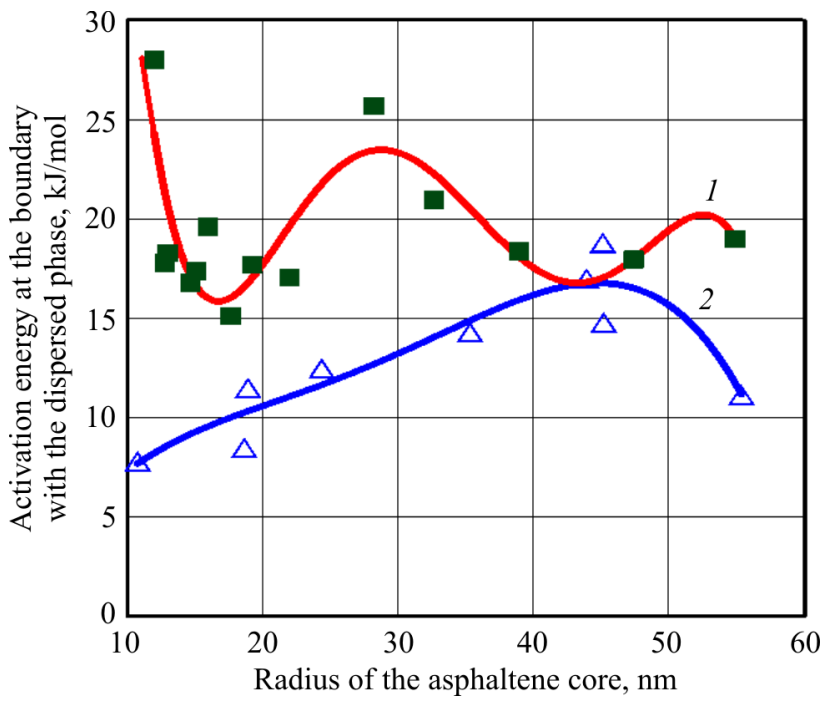

Fig. 3. Change in activation energy at the boundary with the dispersed phase for samples of native oil with a strong (1) and weak (2) asphaltene core

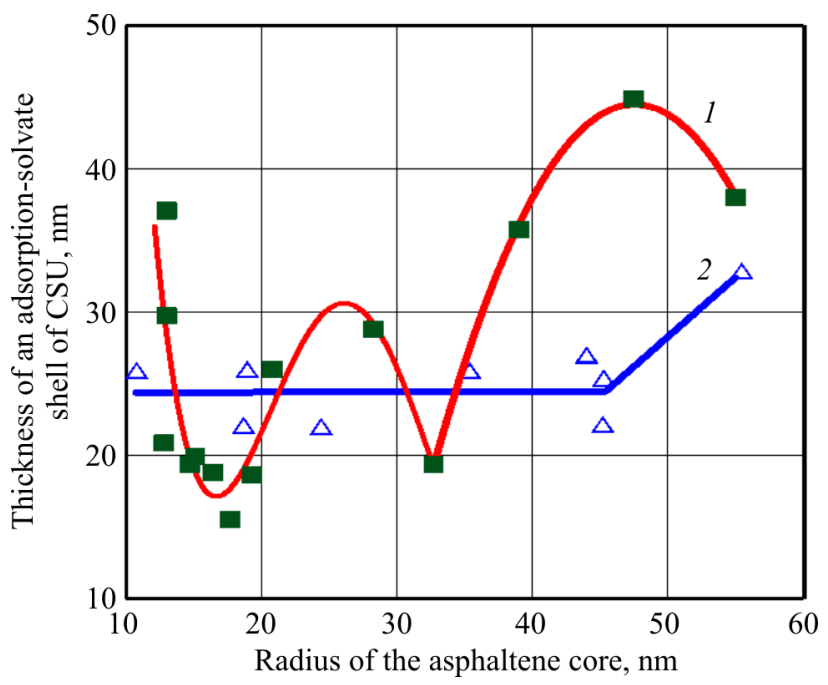

Fig. 4. Interrelation between thickness of the solvate shell and core radius of CSU for native oil samples. Code - oil groups 
At the same time, there is a nonmonotonic process of extreme changes in thickness of a solvate shell observed for the first group with a strong nucleus (see Fig. 4, graph 1) as a function of geometric dimensions of the nucleus with a tendency to increase as the size of the CSU increases. In this case activation energy does not correlate with the screening factor like in the second group.

The structural differences of the CSU complexes in the groups established above suggest that the main reason is the core itself as the central potential force. That force affects all peripheral objects and exchange processes between the nucleus and dispersion medium.

It is assumed that all the CSU nuclei are spherical and have a uniform porosity, since they consist of individual small enough (about 2-2.4 $\mathrm{nm}$ ) compact molecules of asphaltenes [23], but this is not always so. Therefore, in order to study the internal structure of the nucleus itself, representations of the fractal geometry of nanoobjects were used [24, 25].

Today, fractal models of formation of asphaltene nanoaggregates are fruitfully used to describe the processes of self-organization of oil dispersed systems [26, 27]. According to those processes the asphaltene aggregate is a paramagnetic frame of fractal geometry [28]. The main feature is that the radial density function $\rho$ (R) of the fractal aggregate is variable and rapidly decreases in power-law dependence with increasing distance from the center of the aggregate $R$ :

$$
\rho(r)=\rho(0)(R / r)^{D-d},
$$

where $\rho(0)$ - initial density in the center of the unit; $r$ - radius of particles from which the fractal aggregate is assembled; $D$ - fractal (fractional, noninteger) dimension; $d$-dimensions of space (for a sphere $d=3$ ).

Fractal dimension reflects a special property of the aggregate, in particular the maximum level how it could fill the space for a fixed mass. The smaller the fractal dimension of $\mathrm{D}$, the more friable (with a smaller density of dendritic branches) the volumetric nanostructure arises in space and the greater the porosity of the aggregate [9].

Real density of the asphaltene core of native oil sample was estimated using the CSU structural elements obtained from the experiment. If the density of oil is known $\rho_{\mathrm{o}}$, and partial densities of the dispersion medium $\rho_{\mathrm{d} . \mathrm{m}}$, and density of resins $\rho_{\text {res }}$, then it is possible to estimate the average density of asphaltenes in oil in situ without the deposition of asphaltenes by hexane or n-heptane [10].

The Fig. $5 a$ shows average density of the asphaltene core of CSU plotted as a function of the radius for two groups of native oil of different deposits. It is established that as the radius of asphaltene aggregates increases, the density decreases by more than a factor of 2 in terms of the power law, which confirms experimentally the fractal nature of the nucleus of native oil.

However, due to the influence of various statistical factors, the obtained data on the calculated additive three-parameter model in Fig. $5 a$ do not allow to estimate the fractal dimension in each oil group. More accurate methods are used for that. For example, a mass equation is frequently used that relates the number of particles $\mathrm{N}$ in the aggregate and their mass from the radius of the aggregate $[29,30]$ :

$$
N(r)=k(R / r)^{D} .
$$

Using the technique, linear graphs of interconnection between the mass of asphaltene nanoaggregates and nuclear radius for two established oil groups are obtained in double logarithmic coordinates and given in Fig. $5 b$.

That is seen from the Fig. $5 b$ that mass method gives a clear differentiation of the sample in two groups. That also allows to calculate the fractal dimension. The experimental dependences obtained from (2) are described by power equations

$$
\begin{aligned}
& 1^{\text {st }} \text { group }-Y=14.519 \cdot 10^{-3} X^{1.556}, \rho=0.960 \\
& 2^{\text {nd }} \text { group }-Y=2.857 \cdot 10^{-3} X^{2.040}, \rho=0.985
\end{aligned}
$$

It follows that the fractal dimension of the asphaltene core for the oil of the first group is $D=1.556$, respectively for the second -2.040 , and deviation $\Delta D$ between them is $31.1 \%$. Consequently, the first oil group is characterized by a lower, and the second, respectively, high fractal dimension of the asphaltene core.

The results obtained confirmed that the "strong" core, in comparison with the "weak" one, differs by the more complex volume structure of CSU fractal framework. Comparing the 

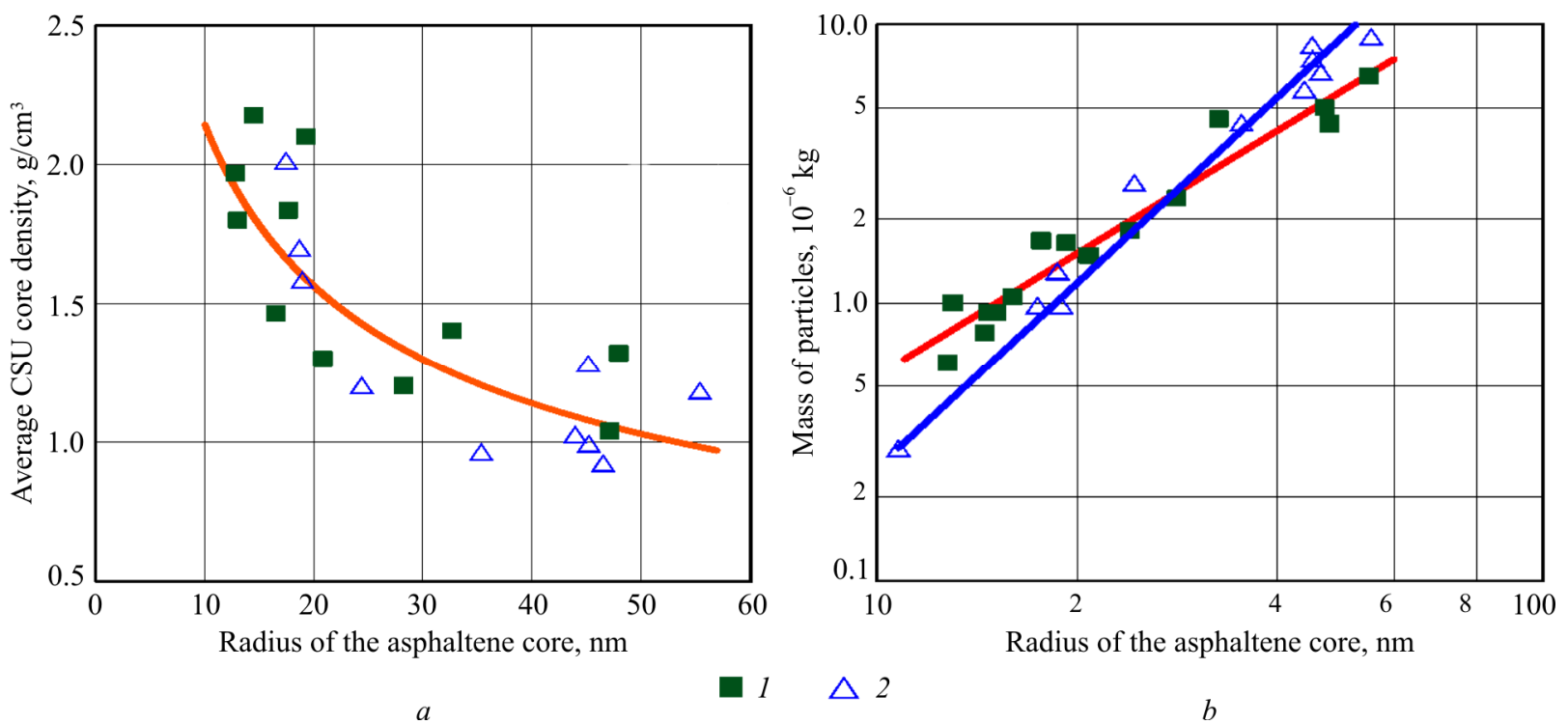

Fig. 5. Dependence of average density of the CSU nucleus $(a)$ and interconnectionsof the mass of asphaltene particles $(b)$ with radius for native oil samples. Code - oil groups

dimensions and results of computer modeling of the growth of fractals $[9,31]$ it follows that in the first group the peripheral asphaltene structures of the nucleus discharged by matter are less correlated in the thermal Brownian motion than in the second group and have more degrees of freedom. That increases the probability of rapid aggregation due to the capture of the volumetric colloidal network of primary asphaltene particles already on the periphery of the nucleus without the possibility of their movement to the central regions of the fractal.

In the second group, branched massive peripheral structures of the nucleus are more connected and inhibited. That increases the probability of radial movement of asphaltene particles and their deposition not only at the periphery but also in the deeper layers of the fractal nucleus, which characterizes the relatively slow process of formation of a more compact mass of the asphaltene aggregate.

According to the size of dimensions $D<1.7$ there are mechanism of diffusion-controlled aggregation in the first oil group and kinetically controlled aggregation of asphaltenes in the second group at $D>2.0[29]$.

\section{Effect of fractal dimensions on macro-properties of oil}

Dynamic viscosity. Oil is a complex dispersed system. If the oil containes asphaltene and resin matter then various features of viscous flow appear [32]. The established fractal features of the structure of the CSU nucleus of two groups of oil have a direct effect on the technological macroparameters of native oil, in particular, the dynamic viscosity. It is known that oil viscosity changes if fractality is considered [33].

Analysis of dependence of oil dynamic viscosity on content of asphaltenes, given in Fig. 6, shows that having the content of asphaltenes changed oil viscosity in groups obeys following equations:

$$
\begin{aligned}
& 1^{\text {st }} \text { group: } \ln Y=0.816 X+1.083, \rho=0.950, \\
& \sigma=0.182 ; \\
& 2^{\text {nd }} \text { group: } \ln Y=0.516 X+0.895, \rho=0.981, \\
& \sigma=0.108 .
\end{aligned}
$$

It can be seen from Eqs. (5) and (6) that experimental data for two groups are well described by a linear model, but the following differences appear. The statistical parameters given in (5) and (6) characterizing the tightness of the bond (dispersion $\sigma$ and correlation coefficient $\rho$ ) show that there is a practically functional dependence of the viscosity on the content of asphaltenes for the second oil group In addition, if we do not include the explicitly fallen off point in Fig. 6 , then $\rho$ is additionally reduced in 5 times and approaches zero, and the correlation coefficient $\rho$ becomes equal to one in this case. 
At the same time, the first group is characterized by a purely statistical relationship, which is characterized by a higher (1.7 times) variance and low correlation coefficient, which indicates the effect of additional statistically significant parameters, in addition to the content of asphaltenes. For example, if the content of asphaltenes is normalized to the radius of the core, i.e. additional introducing the fine features of geometry of a CSU complex into the model, then the tightness of the connection in the first group is significantly increased. This suggests that systems with low fractal dimension, as more complex in structure, require multidimensional models of physical processes for their description.

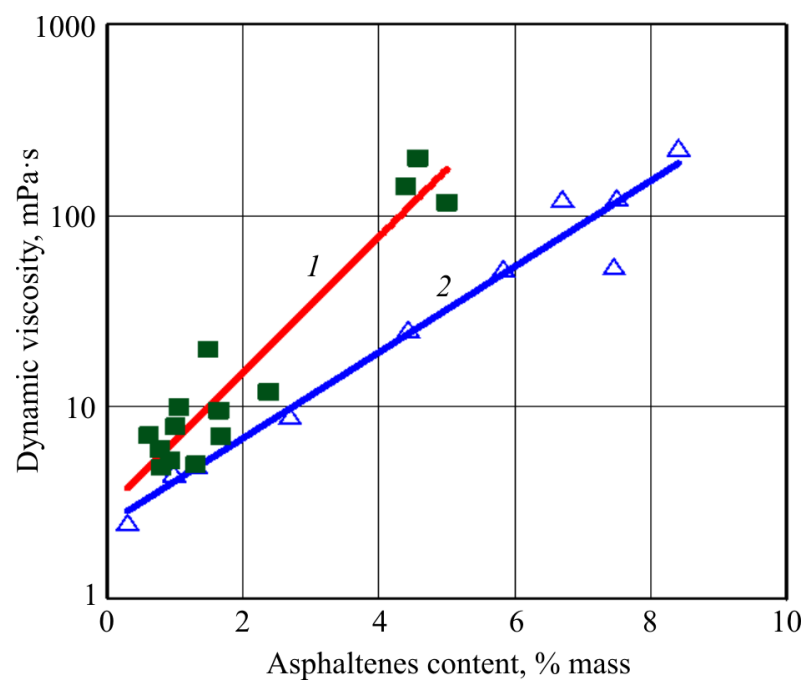

Fig. 6. Dependence of oil dynamic viscosity on the content of asphaltenes for samples of native oil. Code - oil groups

In the quantitative ratio for the first group the viscosity growth rate of the oil is 1.6 times higher, and in absolute terms, with a fixed content of asphaltenes, the viscosity is 1.5-5.0 times higher than in the second group. So, experiments give an incompletely logical picture that with the same mass fraction of the dispersed phase, a higher internal resistance (shear stress) exists between the layers of the dispersion medium (liquid hydrocarbons) in the first group, although the shielding layer of the resin around the nucleus (see Fig. 4) here is more extended. That is explained by the low fractal dimension of the CSU nucleus.

Next, principal (theoretical) possibility of fractal geometry of aggregates effect on viscosity of the oil dispersed system is estimated. It was established by the numerical simulation method that hydrodynamic radius $R_{h}$ and radius of inertia $\mathrm{R}_{\mathrm{g}}$ of aggregates are related to each other by a simple relation

$$
R_{h}=\beta_{h} R_{g},
$$

where for three-dimensional relatively small spherical aggregates the value of $\beta_{h}$ is expressed in terms of fractal dimension D by formula [34]

$$
\beta_{h}=k^{1 / D}\left[\frac{2+D}{D}\right]^{1 / 2},
$$

where $k=1.0 \ldots 1.2$. It follows from (7) and (8) that for the first oil group the calculated hydrodynamic radius will be 1.61 times greater than the radius of inertia and 1.47 times for the second group.

The Einstein-Sima equation was used in order to evaluate the viscosity. The equation tells about cubic dependence of the viscosity $\eta$ from the hydrodynamic (Stokes) radius of particles:

$$
\eta=\frac{4 \pi 2,5 N_{a}}{3 M} R_{h}^{3}
$$

where $N_{a}$ - Avogadro number; $M$ - molecular mass. In our case, increase in $R_{h}$ at the same radii $R_{g}$ aggregates in groups leads, according to (9), with constant other parameters, to the ratio of viscosities $\eta_{1} / \eta_{2}$ in groups equal to 1.3 units, which is close enough to the experimental estimate of 1.5 units obtained earlier for the lower limit of viscosity increase in the first group (see Fig. 6).

The simple ratio (8) no longer works in the region of the upper limit of viscosity, where the condition for the coherent state of asphaltene aggregates is satisfied for high-viscosity oil. It is theoretically impossible to estimate the ratio $\eta_{1} / \eta_{2}$

Thus, decrease in fractal dimensions of the CSU nucleus leads to emergence of higher viscosity and, accordingly, rheological properties of oil at the same content of the dispersed phase in the form of asphaltenes. Hence, fractal asphaltene aggregates are more prone to association and formation of bulk supramolecular structures in oil.

Temperature at which oil saturates with paraffin. Temperature at which oil is saturated with paraffin (TOP) is the second technological parameter which characterizes phase transition of chain n-alkanes $\mathrm{C}_{16} \mathrm{H}_{34}-\mathrm{C}_{36} \mathrm{H}_{74}$ when the temperature decreases with the appearance of new 
phase nuclei in the oil volume and formation of solid paraffin deposits. The higher the TOP, the greater the probability of premature formation of organic deposits of complex composition in production wells, sedimentation tanks, in-line and trunk pipelines, which leads to serious problems and accidents in extraction, transportation and refining of oil $[35,36]$.

As is known, saturation temperature under normal conditions depends on the content of paraffins, asphaltene and resins in oil. In this case, polar asphaltenes and resins can be simultaneously both propagators and inhibitors (terminators) of paraffin deposits [37, 38]. Experiments show, in that case TOP depends on the structure of CSU complexes.

Graphs in Fig. 7 shows dependence of the TOP on structural nanoparameter, which is equal to the ratio of thickness of the adsorption-solvate shell of resins to the radius of the core $h_{a d s} / R$, for two groups with a strong (graph 1) and weak (graph 2) asphaltene core. It can be seen from the figure that the dynamics of TOP differs significantly in selected oil groups.

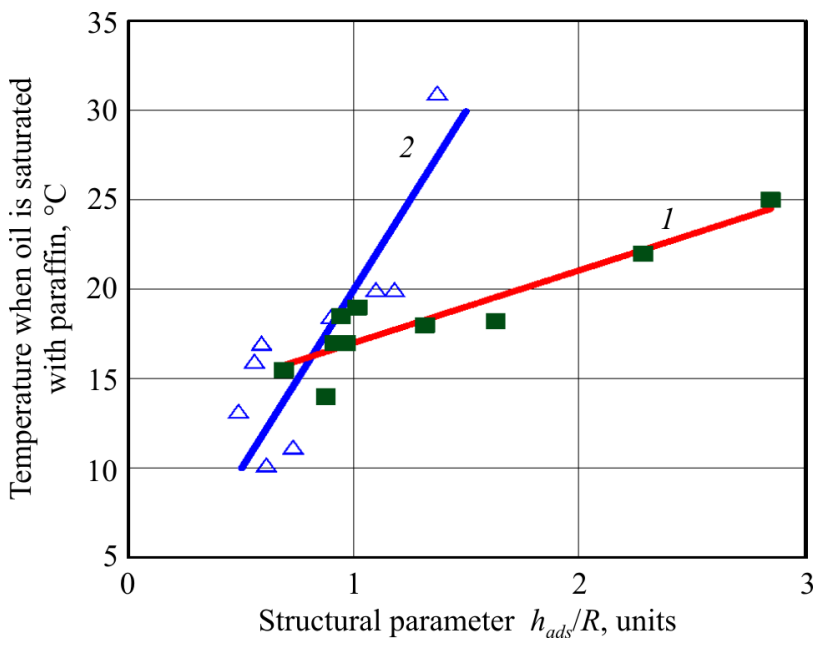

Fig. 7. Dependence of the temperature when oil saturates with paraffin on structural parameter of $h_{\text {add }} / r$ for native oil samples. Code - oil groups

It is found by the experiment that TOP varies according to linear equations if structural parameter CSU is varied

$1^{\text {st }}$ group $-Y=4.047 X+12.955, \rho=0.909 ;(10)$

$2^{\text {nd }}$ group $-Y=19.891 X+0.112, \rho=0.829$. (11)

According to (10) and (11), intensity of change in TOP in the second group is 4.9 times higher in comparison with the first one.
Thus, it can be said that TOP also depends on the fractal dimension of the asphaltene core in addition to all known parameters.

Correlation between the TOP and structural parameter $h_{a d s / r}$ is based on a mechanism that has several rules. Firslty, internal specific surface of adsorption of paraffin molecules increases wih decrease in size of the nucleus. The higher the number of adsorption centers the higher the probability of nucleation of critical embryos at a higher temperature and formation of a solid volumetric network of paraffin crystals. Secondly, when nuclear radius decreases the screening role of structureless resins increases, which act as blockers of inhibitory properties of asphaltenes with respect to paraffins.

Thus, for the second group with constant shell thickness (see Fig. 4) with changes in $h_{a d s} / R$ parameter from 0.5 to 1.3 units TOP value linearly increases to $31{ }^{\circ} \mathrm{C}$ (see Fig. 7) due to reduction in radius to $18.5 \mathrm{~nm}$ and decrease in temperature down to $10{ }^{\circ} \mathrm{C}$ in case of increase in size of nucleus in 2.6 times from the minimum to $48 \mathrm{~nm}$, which corresponds to decrease in paraffin saturation temperature in 3.1 times.

Oil with a thicker nuclear solvation shell in the first group, by analogy, would seem to have a more tangible increase in growth of TOP due to screening compared to the second group. Nevertheless, experiments showed the reverse effect of decrease in both the growth rates and range of real values of TOP of oil.

The observed anomalous effect arises due to special properties of the low-dimensional fractal nucleus CSU, which manifest themselves in presence of long-range action (energy and power) asphaltenes on paraffin molecules. Asphaltenes of the core with shape of radial filamentary branches pierce the solvate shell of resins, are embedded in growing crystals of paraffin, which leads to a violation of their normal growth (size and shape) and further inhibits the process of approaching the crystals and their adhesion to form a solid solid paraffin wax, i.e. effect of inhibition.

Thus, low fractal dimensions of the nucleus stimulate the emergence of the inhibiting properties of asphaltenes with respect to paraffin hydrocarbons. High fractal dimensions reduces and blocks them. 
In practice, the established linear dependence of TOP on structural parameters of CSU (see Fig. 7) opens the possibility of direct control of the process of precipitation of paraffin hydrocarbons during the cooling of oil in tubing or pipeline through the formation of the necessary stable structure of asphalt-shadow complexes due to both a decrease in the thickness of the solvate shell and increase in the radius of the asphaltene core.

Temperature of aggregation of asphaltenes. Since spontaneous increase in sizes of active asphaltene complexes is one of the main reasons for formation of ARP in various technological processes influence of temperature on processes of aggregation of asphaltenes in native oil is considered [39].

As is known, increase in temperature leads to increase in velocity of Brownian motion of molecules and disintegration of bound associative complexes, flocculae, aggregates and chemical bonds in liquid and solid substances, i.e. to destruction of existing order in matter.

During extraction, transportation and storage of petroleum products, technological processes associated not with growth but with slow decrease in temperature of the liquid in a tubing or pipeline. This finally leads to decrease in the aggregative stability factor of the oil dispersed system, which also depends on the fractal dimension of the CSU complexes.

Laboratory temperature studies of native oil were conducted using a technology close to the commercial. Initially, the oil sample was heated above the TOP to $60{ }^{\circ} \mathrm{C}$ and held for $4-5$ hours with periodic mixing in a thermostat until the asphaltene complexes were completely destroyed and dissolved in oil. Then the sample was placed in a sealed thermostat container, temperature of the oil in it was gradually decreased in steps of 5 degrees in the range from 60 to $3-5{ }^{\circ} \mathrm{C}$ and held at each stage for 40 minutes. During the such slow step-by-step lowering of the temperature by NMR, restructuring of the nanostructure of the CSU of native oil due to change in mean radius of the asphaltene core was monitored.

The Fig. 8 shows an example of temperature dependences of the growth dynamics of the CSU nucleus radius in aggregation of asphaltene particles for two viscous samples of native oil. It can be seen that in the entire range from 60 to $5^{\circ} \mathrm{C}$ a close to linear inverse model of aggregation is performed, which is characterized by an average angular coefficient (aggregation coefficient) $\alpha=d R / d T$ ( $R$ - radius of the nucleus, $T-$ temperature) of the evaluation line. This parameter quantitatively reflects the intensity of the effect of uniform oil cooling on the resulting structural size of the CSU nucleus during the aggregation of asphaltene particles.

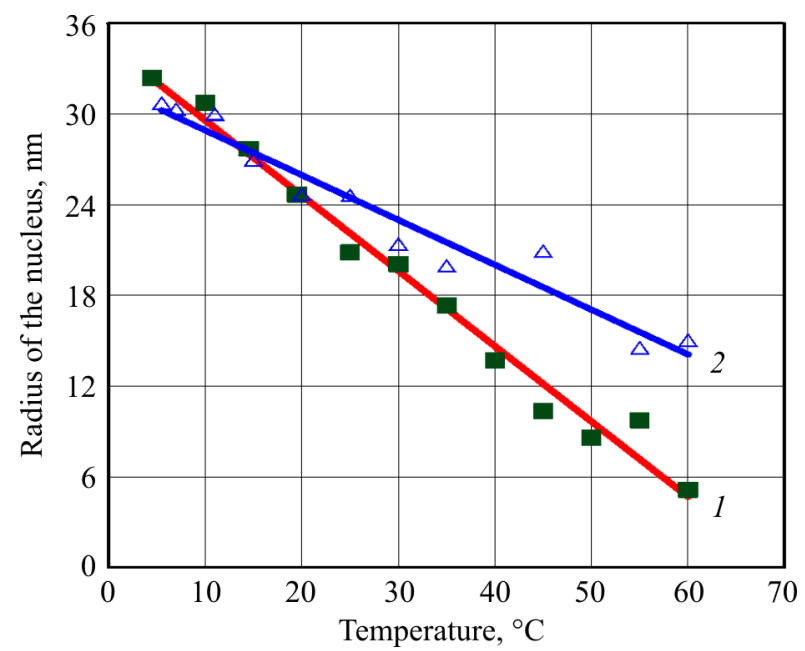

Fig. 8. Dynamics of change in radius of asphaltene core from temperature and angle of inclination for viscous samples of native oil of Mosinskoe (1) and Kanakhinskoe (2) fields

The experiments conducted showed that aggregation processes have characteristic features that make up from the fractal dimension of the nucleus of native oil. In particular, decrease in fractal dimension leads to an increase in aggregation rate of asphaltene particles, i.e. increase in angular coefficient of the kernel growth chart. Thus, as it seen from the Fig. 8, aggregation coefficient for the Well 235 of the Mosinskoe oil field from the first group with lower $(D=1.556)$ nucleus dimension is equal to $0.499 \mathrm{~nm} /$ degree, and $0.297 \mathrm{~nm} / \mathrm{deg}$ for the Well 71 of Kanakhinskoe oil field of the second group $(D=2.040)$. In general, average aggregation coefficient $\alpha_{1 \text { av }}$ for the first group of native oil is 3.6 times higher than the coefficient $\alpha_{2 a v}$ in comparison with the second group (0.391 against $0.110 \mathrm{~nm} /$ degree) .

The features obtained are explained by the fact that low-dimensional structure of CSU nucleus has internal adsorption surface and surface energy controlling its reactive and solvating activity much higher than in high-dimensional nucleus due to 
more branched, flexible and mobile asphaltenic framework. That framework is capable of conformational transformations, which reduces steric hindrances and enthalpy of association upon contact and "clumping" of aggregates such as "particle-cluster" or "cluster-cluster" and causes real increase in intensity of aggregation with decrease in oil temperature.

An additional regularity has been established. The process of aggregation of asphaltene particles depends both on fractal dimensions and initial size of the nucleus-beam (growth center) from which aggregation begins. In case the equilibrium radius of the nucleus is taken as the starting point for oil samples at room temperature $\left(25^{\circ} \mathrm{C}\right)$ then the picture below is experimentally obtained.

For oil of the second high-dimensional group, as the radius of the initial growth center increases, the coefficient of thermal aggregation $\alpha_{2}$ (Fig. 9, graph 2) decreases monotonically, which is well described by an equation of the form

$$
Y=-0.1732 \ln X+0.7902, \rho=0.952 \text {. }
$$

That means the aggregation of asphaltenes into relatively small clusters occurs with a higher intensity $\left(\alpha_{2}=0.37 \mathrm{~nm} / \mathrm{deg}\right.$ at $\left.R=10 \mathrm{~nm}\right)$ than for larger ones $\left(\alpha_{2}=0.10 \mathrm{~nm} / \mathrm{deg}\right.$ at $\left.R=55 \mathrm{~nm}\right)$.

Having temperature drop in the range from 55 to $5{ }^{\circ} \mathrm{C}$, the average absolute increment of $\Delta R$ in large aggregates is $5.5 \mathrm{~nm}$ and $20.4 \mathrm{~nm}$ in small ones. In other words.

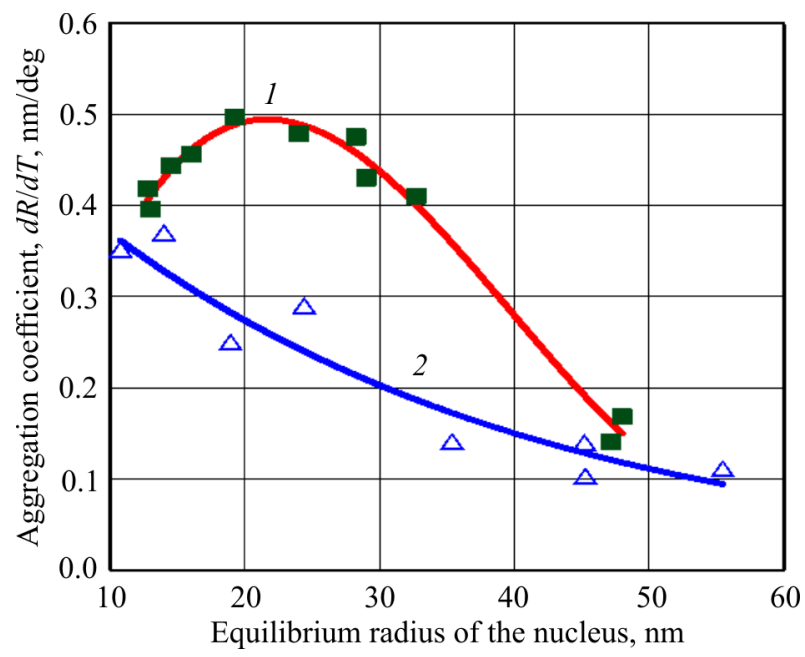

Fig. 9. Dependence of the coefficient of temperature aggregation of asphaltenes from the equilibrium radius of the nucleus for two groups of oil
Large aggregates have a relatively small increase in radius by $15-18 \%$ while the size of the nucleus is significant and amounts to $150-200 \%$, i.e. significantly exceeds the initial seed size.

The monotonous decrease found in aggregation $\alpha_{2}$ is explained by the fact that at the equilibrium radius of the nucleus from 10 to $45 \mathrm{~nm}$, firstly, linear growth of the potential barrier is observed activation energy from 7.5 to $17 \mathrm{~kJ} / \mathrm{mol}$ (see Fig. 3, graph 2), which inhibits and limits the aggregation of particles. Secondly, experiments show that the solvate number $Z$ decreases from 1.6 to 1.05 units as the diameter of the adsorption center increases, i.e. the number of contacting particles in the first coordinate sphere of the nucleus. Superposition of that negative parameters of the kinetic factor leads to a decrease in the probability of approach and subsequent collision of particles with the nucleus, which is responsible for the expected decrease in the aggregation coefficient with increase in the equilibrium radius.

Thus, in spite of the small content of asphaltenes in $0.3-1.3 \%$ by weight in a lightweight oil of the second group, precipitation of ARP due to the increased temperature aggregation will be formed in the tubing quite intensively, which is confirmed by numerous commercial data. At the same time, phase transition of paraffins is the main reason for precipitation of ARP in heavy and viscous oil. Thermal aggregation of asphaltenes is shifted to the background due to extremely low contribution.

The monotonic character of the dependence established by (12) (see Fig. 9, graph 2) confirms the presence in the second group of native oil of a more homogeneous porosity nucleus, which becomes similar (in terms of its properties) to bodies with a constant density.

Considering the process of aggregation for the first group of oil, as was shown above (see Fig. 3, 4), the oil of a low-dimensional group is characterized by the emergence of structural and energy extremal states. This feature was also established by us during the study of thermal aggregation of asphaltenes. In particular, with initial increase in beam radius in the light oil of the first group, intensity of aggregation of asphaltenes does not decrease as in the second group, on the contrary, increases sharply, reaching a maximum of $0.5 \mathrm{~nm} / \mathrm{deg}$ at the maximum 
(see Fig. 9), which is well described by a polynomial equation

$$
\begin{aligned}
Y= & -0.1383+0.0668 X-0.002 X^{2}+ \\
& +1.7783 \cdot 10^{-5} X^{3}, \quad \rho^{2}=0.995 .
\end{aligned}
$$

After the extremum is passed the intensity of temperature aggregation decreases. Nevertheless, the differentiation condition is always satisfied and looks like $\alpha_{1 i}>\alpha_{2 i}$, where $i$ is the effective radius of a beam.

The extreme dependence established reflects nonlinear properties of asphaltene aggregates. At the extremum point the derivative $d \alpha_{1} / d R$ is zero, which reflects the condition for a weak dependence of the intensity of temperature aggregation on the seed radius and other macro properties of oil (viscosity, density, ARM). There is a balance of forces established in the extreme state that simultaneously stimulates and blocks the thermal aggregation of asphaltenes. Thus, beyond the extreme boundary, the accelerated abnormal aggregation of asphaltenes prevails with a shift to the left, and mechanism of a normal decrease in aggregation intensity prevails when shifting to the right.

From a formal point of view, an extremum arises when a function or a physical process is not described by a simple linear equation with respect to a controlling parameter (argument). In particular, the graph 1 in Fig. 9 is modeled by a polynomial of the third degree (13), which in addition to the large linear contribution contains small additive terms (small corrections) that are different in weight and different in sign with arguments of the second and third degree. Nonlinearity characterizes the ambiguous relationship between the argument and function, which is due to the presence of several roots (real or imaginary) of the solution of the equation. In terms of physics, that may be a consequence of the influence on the process of several control parameters, the so-called kinetic coefficients.

The estimates above relate to the phenomenological description of the thermal growth of nuclear sizes. The mechanism of manifestation of anomalous aggregation, which characterizes the nonlinear properties of asphaltenes, is the most interesting over the all features of the process.
Analysis of experimental data shows that anomalous (reverse) in direction aggregation at the initial seed interval from 12 to $18 \mathrm{~nm}$ is realized when the synergistic action of the the components of the kinetic factor is combined such as presence of a local minimum $(15 \mathrm{~kJ} / \mathrm{mol}$ vs. an average of $19 \mathrm{~kJ} / \mathrm{mol}$ ) of activation on the border with asphaltenes (see Fig. 3, graph 1), local minimum $(15.5 \mathrm{~nm}$ vs. average at $26.6 \mathrm{~nm})$ thickness of the solvate shell (see Fig. 4, graph 1) and high $(Z=1.7$ units) of the solvate number of the nucleus. Each of them determines the probability of implementing a separate stage of a complex dynamic aggregation process, and the product of the probabilities of physical quantities determines the final probability of the process as a whole. Thus, a solvate number growths and provides a statistically significant number of active particles near the nucleus, a low activation barrier facilitates the approximation of aggregating particles and small thickness of the protective shell facilitates direct contact of the particle with the nucleus and formation of a new stable structure of the aggregate. Eventually, kinetic energy of the reacting particles is converted into the potential energy of interparticle bonds, and temperature aggregation index increases by an abrupt increase of $25 \%$, although, it should decrease slowly with increasing beam sizes. It should be noted that the process observed characterizes only fractal asphaltene aggregates with a low core dimension.

Thus, as the fractal dimension of the nucleus decreases, the number of possible microstates (degrees of freedom) of the system increases, which, according to L.E. Boltzmann corresponds to increase in system's entropy. Increase in entropy reflects the fact that the structure of CSU became less ordered (irregularity, chaos), which plays a role of generator of the high extremal activity of the CSU nucleus, which controls the macroproperties of native oil, decreases in order.

Quantitative estimates carried out from the data in Fig. 9 show that for the oil of the first group in subcritical mode, the slope of the angle $d \alpha_{1} / d R$ of the left branch of the graph 1 describing the anomalous aggregation is $+16.7 \cdot 10^{-3}$ fractions of unit, and in the overcritical region of the normal decay, respectively, $13.3 \cdot 10^{-3}$ fractions of units. At the same time for the second oil group, the 
analogous decline $d \alpha_{2} / d R$ of aggregation of asphaltenes is $-6.25 \cdot 10^{-3}$ fractions of unit, which is 2.1 times less than for the first group.

It follows that oil with a lower fractal dimension of the nucleus is more prone to aggregate and form the ARP deposits when temperature is decreased.

\section{Effectiveness of ARP deposit inhibitors}

Let's have a look at the results of experiments on the direct observation of ARP deposits on a metallic surface. One of the methods for preventing deposition of AFS is chemical inhibitors.

When an inhibitor, which is a surfactant, is dissolved in oil, adsorption occurs on the interfacial surface of the CSU, which leads to a change in the internal structure of the liquid and transition of oil dispersion system into a new thermodynamic state. In particular, we showed in [11] that an effective inhibitor leads to a decrease (peptization) of the mean radius of the asphaltene CSU nucleus and increase in activation energy $\mathrm{E}_{\mathrm{a}}$ of molecules of dispersion medium. In order to estimate the weight of ARP deposits on the metal surface after oil treatment with inhibitors, we obtained an analytical equation [40] that relates the mass of paraffin deposits to energy parameter $\Delta E_{a}$ of liquid molecules:

$$
Y=1-U \Delta E_{a},
$$

where $Y$-relative mass equal to the ratio of weight of ARP matter after treatment to mass of deposits before treatment with oil inhibitor, $Y=\mathrm{m}^{\mathrm{inh}} / \mathrm{m}^{\text {ini }}$, $U$ - oil constant; $\Delta E_{a}-$ difference $\left(E_{a}^{\text {inh }}-E_{a}{ }^{\text {ini }}\right)$ activation energy with and without an inhibitor.

An efficiency coefficient $E$ used in practice is calculated using the equation (14), that shows relative decrease in weight of ARP deposits on the metal surface after oil is being treated with an inhibitor:

$$
E=1-Y=U \Delta E_{a} .
$$

Thus, the effectiveness of the inhibitor is proportional to the difference in the activation energy of $\Delta E_{a}$ hydrocarbons with a positive sign, showing how much this inhibitor can increase the potential barrier for dispersion medium molecules that directly controls the growth and adhesion of paraffin crystals.
The Fig. 10 shows the results of the cold plate method of laboratory experiments testing five different inhibitors of ARP deposits of SNPCH using samples of two oil groups differing in fractal dimensions of the asphaltene nucleus.

Firstly, it can be seen that the experiments confirm the theory (15) on example of use of different in physical and chemical properties of oil and chemical reagents. The obtained dependences on the effectiveness of the ARP deposits inhibitors are described by linear equations which are as follows:

$$
\begin{aligned}
& 1^{\text {st }} \text { group } \\
& \mathrm{E}=-0.0755 \Delta E_{a}+0.015, \rho=0.992, \\
& 2^{\text {nd }} \text { group } \\
& \mathrm{E}=-0.0480 \Delta E_{a}+0.021, \rho=0.999 .
\end{aligned}
$$

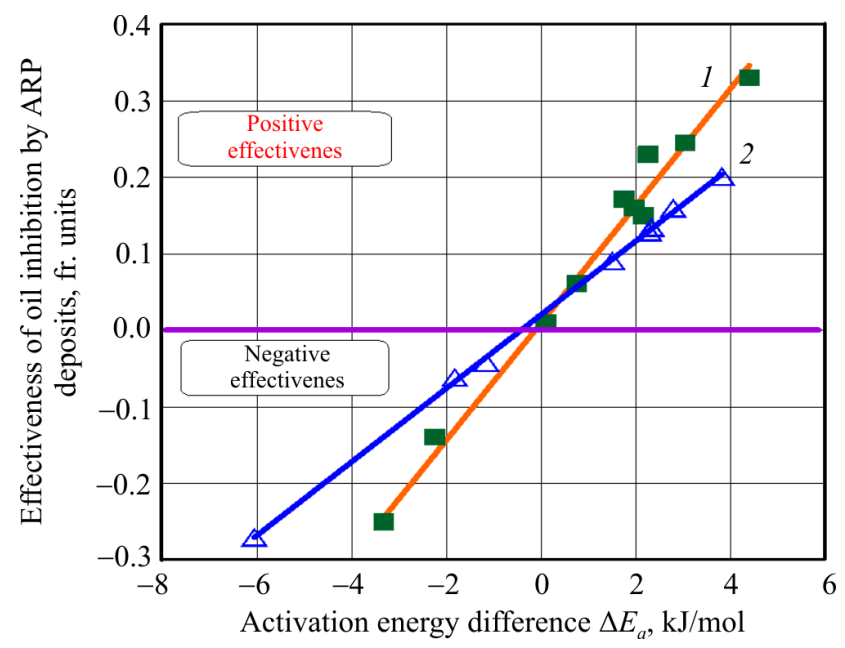

Fig. 10. Dependence of effectiveness of inhibition of ARP deposits on a metal surface on the difference in activation energy of a dispersion medium after treatment of two oil groups with different fractal dimensions

Secondly, a clear difference in dynamics of relative weight of ARP deposits by oil groups was obtained. In particular, the intensity of $d E / d \Delta E_{a}$ of inhibition of ARP deposits in the first group is 1.6 times larger than in second one, which exactly coincides with the analogous coefficient when comparing the dynamic viscosity (see Fig. 6).

Third, oil with low fractal dimensions shows a higher positive efficiency when treated with different inhibitors. So, for example, comparing the inhibitor that increases activation energy by $+4 \mathrm{~kJ} / \mathrm{mol}$, the average efficiency of reducing the 
weight of the ARP deposits for the second oil group is $21.3 \%$, and $31.7 \%$ in the first one which gives a difference of $48.8 \%$ rel.

According to the negative effect (see Fig. 10), which often leads to increase in weight of ARP deposits when treated with inhibitors, as compared to a blank sample, the first group with a low-dimensional CSU nucleus is also leading.

A negative effect, especially in the case of heavy viscous oil, arises when the chemicals start in the disperse system the negative growth processes of the radius of the asphaltene CSU nucleus and reduce threshold energy of oil activation, which gives a negative sign of difference in $\Delta E_{a}$ in (15), which is generally stimulating more intensive growth of paraffin crystals and increase in their mass with adhesion on the surface of equipment [6].

As a result of the set of studies carried out, it was shown that the change in the fractal dimension of asphaltene aggregates of CSU due to external factors and physical and chemical fields can cause abnormal behavior of oil's technological properties (viscosity, mobility, TOP, aggregation of asphaltenes and precipitation of ARP deposits), which is not a subject to the additivity law. The established correlation of nano-properties and macro-characteristics of native oil in terms of methology allows more reasonably searching for and developing new, including non-traditional, methods for increasing the efficiency of technological processes in oil and gas industry.

The results obtained in the work can be used in practice while improving modern methods of controlling the properties of oil dispersed systems in development, production and refinery of hydrocarbons.

\section{Conclusions}

1. A complex analysis of energy and structural features of the structure of asphaltene nanoaggregates was carried out experimentally and fractal dimensions of CSU nucleus were calculated for two alternative groups of native oil, which is 2.040 and 1.556 units.

2. It is established that oil with low fractal dimensions of the nucleus has a higher (by 1.5-5.0 times) dynamic viscosity, and theoretical substantiation of this physical phenomenon is carried out.

3. It is revealed that oil with low fractal dimension due to its structural features has an increased natural inhibition ability of the asphaltenes of the core in relation to growth and precipitation of solid paraffins forming ARP deposits.

4. According to the data of temperature studies, it is established that dynamics of growth of the radius of the CSU nucleus during the aggregation of asphaltene particles is well described by the linear model, while the aggregation intensity is on the average higher by 3.6 times in oil with a lower fractal dimension.

5. It is additionally determined that the coefficient of thermal aggregation of asphaltenes depends on the radius of the initial seed and for oil with a high fractal dimension is described by a monotonic logarithmic model.

6. Anomalous nonlinear aggregation is established for oil with low dimensions at small radii of the initial beam, which violates the monotonous nature of change in aggregation coefficient.

7. According to results of the experiments, it was established that effectiveness of action of the ARP inhibitors in oil with low fractal dimension is $5-49 \%$ higher compared to the group of highdimensional oil.

\section{References}

1. GOST P55416-2013/ISO/TS 80004-1:2010. Natsionalnyi standart Rossiiskoi Federatsii. Nanotekhnologii. Part 1. Osnovnye terminy i opredeleniia [National Standard of the Russian Federation. Nanotechnology. Part 1. Basic terms and definitions], available at: http://docs.cntd.ru/document/ 1200103381 (accessed 12 February 2018).

2. ISO/TS 80004-1:2010 Nanotechnologies. Vocabulary. Part 1: Core terms, available at: http://shop.cntd.ru (accessed 12 February 2018).
3. Malinetskii G.G. Nanotekhnologii. Ot alkhimii k khimii i dalshe [Nanotechnology. From alchemy to chemistry and beyond]. Integral, 2007, no.5, pp.4-5.

4. Khavkin A.Ia. Nanotekhnologii v dobyche nefti [Nanotechnologies in an oil recovery]. Oil industry, 2007, no.6, pp.58-60.

5. Khavkin A.Ia. Nanotekhnologicheskie perspektivy neftedobychi [Nanotechnological prospects for oil production]. Burenie i neft, 2009, no.7-8, pp.16-19. 
6. Evdokimov I.N., Losev A.P. Neftianye nanotekhnologii - preodolenie stereotipov [Petroleum Nanotechnology - Overcoming Stereotypes]. Oil industry, 2008, no.8, pp.78-81.

7. Zlobin A.A. Teoriia i praktika primeneniia iadernogo magnitnogo rezonansa $v$ fizike neftianogo plasta [Theory and practice of the application of nuclear magnetic resonance in the physics of the oil reservoir]. Perm, Izdatelstvo PM, 2015, 272 p.

8. Zlobin A.A. Experimental research of nanoparticle aggregation and self-assembly in oil dispersed systems. Perm Journal of Petroleum and Mining Engineering, 2015, no.15, pp.57-72. DOI: 10. 15593/2224-9923/2015.15.7

9. Zlobin A.A. Study of structural organization of oil dispersed systems Perm Journal of Petroleum and Mining Engineering, 2015, iss.17, pp.41-53. DOI: $10.15593 / 2224-9923 / 2015.17 .5$

10. Zlobin A.A. Izuchenie fraktalnykh svoistv neftianykh dispersnykh sistem [Study of fractal properties of petroleum disperse systems]. Tendentsii razvitiia nauki $i$ obrazovaniia: sbornik nauchnykh trudov. Samara, 2016, part 1, pp.27-37. DOI: 10.18411/1j2016-2-08

11. Zlobin A.A., Protopopov A.A. Strukturnoenergeticheskii metod vybora ingibitorov parafinovykh otlozhenii [Structural and energy method for selection of paraffin deposits inhibitors]. Oil industry, 2014, no. 6, pp.48-51.

12. Zlobin A.A. O mekhanizme magnitnoi aktivatsii nefti dlia zashchity skvazhin ot asfaltosmoloparafinovykh otlozhenii [About the mechanism of magnetic activation of oil for the protection of wells from wax deposits]. Oil industry, 2017, no.1, pp.52-56.

13. Ganeeva Iu.M., Iusupova T.N., Romanov G.V. Asfaltenovye nanoagregaty: struktura, fazovye prevrashcheniia, vliianie na svoistva neftianykh sistem [Asphalten nano-aggregates: structure, phase transformations, influence on the properties of oil systems]. Uspekhi khimii, 2011, vol.80, no.10, pp.1034-1050.

14. Siuniaev R.Z. Makromolekuliarnaia organizatsiia i fiziko-khimicheskie svoistva oleodispersnykh (neftianykh) sistem [Macromolecular organization and physical and chemical properties of oleodispersed (petroleum) systems]. Doctor's degree dissertation. Moscow, 1999, 347 p.

15. Deriagin B.V., Churaev N.V., Muller V.M. Poverkhnostnye sily [Surface forces]. Moscow, Nauka, 1985, 300 p.

16. Summ B.D., Ivanova N.I. Kolloidnokhimicheskie aspekty nanokhimii - ot Faradeia do Prigozhina [Colloidchemical aspects of nanochemistry - from Faraday to Prigogine]. Vestnik Moskovskogo gosudarstvennogo universiteta. Seriia: Khimiia, 2001, vol.42, no.5, pp.300-305.

17. Frolov Iu.G. Kurs kolloidnoi khimii. Poverkhnostnye iavleniia i dispersnye sistemy [Colloidal chemistry course. Surface phenomena and disperse systems]. Moscow, Khimiia, 1989, 464 p.

18. Siuniaev Z.I., Siuniaev R.Z., Safieva R.Z. Neftianye dispersnye sistemy [Petroleum disperse systems]. Moscow, Khimiia, 1990, 224 p.
19. Safieva R.Z. Fizikokhimiia nefti. Fiziko-khimicheskie osnovy tekhnologii pererabotki nefti [Physical chemistry of oil. Physical and chemical bases of oil refining technology]. Doctor's degree dissertation. Moscow, 1998, 310 p.

20. Kostin A.S., Koltsova E.M. K voprosu o mekhanizme agregatsii nanochastits dioksida titana [On the mechanism of aggregation of titanium dioxide nanoparticles]. Fundamentalnye issledovaniya, 2012, no.6, part.3, pp.647-651.

21. Smoluchowski N.V. Versuch einer mathematischen Theorie der Koagulationskinetik Kolloider Losungen. Z. Phys.Chem, 1916, vol.92, pp.129-168.

22. Zlobin A.A., Iushkov I.R. Izuchenie struktury neftianykh dispersnykh sistem [Studying the structure of petroleum disperse systems] Problemy kompleksnogo osvoeniia mestorozhdenii poleznykh iskopaemykh v Permskom krae. Sbornik materialov kraevoi nauchno-tekhnicheskoi konferentsii. Perm, Izdatelstvo Permskogo gosudarstvennogo tekhnicheskogo universiteta, 2007, pp.32-41.

23. Sergienko S.R., Taimova B.A., Talalaev E.I. Vysokomolekuliarnye neuglevodorodnye soedineniia nefti [High molecular weight non-hydrocarbon compounds of oil]. Moscow, Nauka, 1979, 270 p.

24. Feder E. Fraktaly [Fractals]. Moscow, Mir, 1991, 260 p.

25. Smirnov B.M. Fraktalnye klastery [Fractal clusters]. Uspekhi fizicheskikh nauk, 1986, vol.149, no.2, pp.178-219.

26. Mukhametzianov I.Z., Kuzeev I.R., Voronov V.G., Spivak S.I. Strukturnaia organizatsiia neftianykh dispersnykh sistem [Structural organization of petroleum disperse systems]. Doklady Akademii nauk, 2002, vol.387, no.3, pp.353-356.

27. Mukhametzianov I.Z. O primenimosti modelei fraktalnogo rosta $\mathrm{k}$ opisaniiu strukturoobrazovaniia $\mathrm{v}$ neftianykh dispersnykh sistemakh [On the applicability of fractal growth models to the description of structurization in petroleum disperse systems]. Kolloidnyi zhurnal, 1991, vol.53, no.3, pp.503-508.

28. Unger F.G., Andreeva L.N. Fundamentalnye aspekty khimii nefti. Priroda smol i asfaltenov [Fundamental aspects of oil chemistry. The nature of resins and asphaltenes]. Novosibirsk, Nauka, Sibirskaia izdatelskaia firma RAN, 1995, 192 p.

29. Roldugin V.I. Svoistva fraktalnykh dispersnykh sistem [Properties of fractal disperse systems]. Uspekhi khimii, 2003, vol.72, iss.11, pp.1027-1054.

30. Smirnov B.M. Fizika fraktalnykh klasterov [Physics of fractal clusters]. Moscow, Nauka, 1991, 136 p.

31. Bulavin L.A., Vygornitskii N.V., Lebovka N.I. Kompiuternoe modelirovanie fizicheskikh sistem [Computer simulation of physical systems]. Dolgoprudnyi, Intellekt, 2011, $352 \mathrm{p}$.

32. Evdokimov I.N., Eliseev N.Iu. Osobennosti viazkogo techeniia zhidkikh sred so smolistoasfaltenovymi veshchestvami [Features of viscous flow of liquid media with resin-asphaltenes]. Khimicheskaia tekhnologiia topliv i masel, 1999, no.6, pp.32-34.

33. Lesin V.I., Lesin S.V. Fraktalnaia formula zavisimosti viazkosti neniutonovskoi zhidkosti ot gradienta skorosti [Fractal formula for the dependence of 
the viscosity of a non-Newtonian fluid on a gradient of velocity]. Oil industry, 2012, no.3, pp.46-48.

34. Gmachowski L. Hydrodynamics of aggregated media. Journal of Colloid and Interface Science, 1996, vol.178, iss.1, pp.80-86. DOI: 10.1006/jcis.1996.0095.

35. Persiiantsev M.N. Dobycha nefti v oslozhnennykh usloviiakh [Extraction of oil under complicated conditions]. Moscow, Nedra-Biznes-tsentr, $2000,653 \mathrm{p}$.

36. Mazepa B.A. Zashchita neftepromyslovogo oborudovaniia ot parafinovykh otlozhenii [Protection of oilfield equipment from paraffin deposits]. Moscow, Nedra, 1972, 120 p.

37. Tronov V.P. Mekhanizm obrazovaniia smoloparafinovykh otlozhenii i borba $\mathrm{s}$ nimi [Mechanism of formation of resin-paraffin deposits and the fight against them]. Moscow, Nedra, 1970, 192 p.
38. Glushchenko V.N., Silin M.A., Gerin Iu.G. Neftepromyslovaia khimiia. Vol. V. Preduprezhdenie i ustranenie asfaltenosmoloparafinovykh otlozhenii [Oilfield chemistry. Vol. V. Prevention and elimination of asphaltenosum-paraffin deposits]. Moscow, InterkontaktNauka, 2009, 475 p.

39. Guckova I.A., Tronov V.P., Gilmanova D.R. Formirovanie asfaltosmoloparafinovykh otlozhenii $\mathrm{v}$ razlichnykh tekhnologicheskikh elementakh neftedobyvaiushchei sistemy [Formation of wax deposits in various technological elements of the oil-extraction system]. Oil industry, 2008, no.3, pp.86-87.

40. Zlobin A.A., Mordvinov V.A., Iushkov I.R. Energiia aktivatsii uglevodorodov nefti kak kriterii vybora ingibitorov parafinovykh otlozhenii [The activation energy of hydrocarbons as a criterion for the selection of paraffin deposit inhibitors]. Neft, gaz i biznes, 2011, no.9, pp.50-54.

\section{Библиографический список}

1. ГОСТ P55416-2013/ISO/TS 80004-1:2010. Национальный стандарт Российской федерации. Нанотехнологии. Часть 1. Основные термины и определения [Электронный pecypc]. - URL: http://docs.cntd.ru/ document/1200103381 (дата обращения: 12.02.2018).

2. ISO/TS 80004-1:2010 Nanotechnologies. Vocabulary. Part 1: Core terms [Электронный pecypc]. - URL: http://shop.cntd.ru (дата обращения: 12.02.2018).

3. Малинецкий Г.Г. Нанотехнологии. От алхимии к химии и дальше // Интеграл. - 2007. - № 5. - С. 4-5.

4. Хавкин А.Я. Нанотехнологии в добыче нефти // Нефтяное хозяйство. - 2007. - № 6. - С. 58-60.

5. Хавкин А.Я. Нанотехнологические перспективы нефтедобычи // Бурение и нефть. - 2009. - № 7-8. C. 16-19.

6. Евдокимов И.Н., Лосев А.П. Нефтяные нанотехнологии - преодоление стереотипов // Нефтяное хозяйство. -2008 . - № 8. - С. 78-81.

7. Злобин А.А. Теория и практика применения ядерного магнитного резонанса в физике нефтяного пласта. - Пермь: Изд-во ПМ, 2015. - 272 с.

8. Злобин А.А. Экспериментальные исследования процессов агрегации и самосборки наночастиц в нефтяных дисперсных системах // Вестник Пермского национального исследовательского политехнического университета. Геология. Нефтяное и горное дело. - 2015. № 15. - C. 57-72. DOI: 10. 15593/2224-9923/2015.15.7

9. Злобин А.А. Изучение структурной организации нефтяных дисперсных систем // Вестник Пермского национального исследовательского политехнического университета. Геология. Нефтяное и горное дело. - 2015. Вып. 17. - С. 41-53. DOI: 10. 15593/2224-9923/2015.17.5

10. Злобин А.А. Изучение фрактальных свойств нефтяных дисперсных систем // Тенденции развития науки и образования: сб. науч. трудов по материалам XI Междунар. науч.-практ. конф., 29 февраля 2016 г. Самара, 2016. - Ч. 1. - С. 27-37. DOI: 10.18411 /lj2016-2-08
11. Злобин А.А., Протопопов А.А. Структурноэнергетический метод выбора ингибиторов парафиновых отложений // Нефтяное хозяйство. - 2014. - № 6. - С. 48-51.

12. Злобин А.А. О механизме магнитной активации нефти для защиты скважин от асфальтосмолопарафиновых отложений // Нефтяное хозяйство. 2017. - № 1. - С. 52-56.

13. Ганеева Ю.М., Юсупова Т.Н., Романов Г.В. Асфальтеновые наноагрегаты: структура, фазовые превращения, влияние на свойства нефтяных систем // Успехи химии. - 2011. - Т. 80, № 10. - С. 1034-1050.

14. Сюняев Р.3. Макромолекулярная организация и физико-химические свойства олеодисперсных (нефтяных) систем: дис. ... д-ра физ.-мат. наук. - М.: РГУНиГ им. И.М. Губкина, 1999. - 347 с.

15. Дерягин Б.В., Чураев Н.В., Муллер В.М. Поверхностные силы. - М.: Наука, 1985. - 300 с.

16. Сумм Б.Д., Иванова Н.И. Коллоиднохимические аспекты нанохимии - от Фарадея до Пригожина // Вестник Моск гос. ун-та. Серия: Химия. - 2001. - Т. 42, № 5. - С. 300-305.

17. Фролов Ю.Г. Курс коллоидной химии. Поверхностные явления и дисперсные системы. 2-е изд. - М.: Химия, 1989. - 464 с.

18. Сюняев 3.И., Сюняев Р.З., Сафиева Р.З. Нефтяные дисперсные системы. - М., Химия, 1990. - 224 с.

19. Сафиева Р.3. Физикохимия нефти. Физикохимические основы технологии переработки нефти: дис. ... д-ра техн. наук. - М.: РГУНиГ им. И.М. Губкина, 1998. - 310 с.

20. Костин А.С., Кольцова Э.М. К вопросу о механизме агрегации наночастиц диоксида титана // Фундаментальные исследования. - 2012. - № 6, ч. 3. C. 647-651.

21. Smoluchowski N.V. Versuch einer mathematischen Theorie der Koagulationskinetik Kolloider Losungen // Z. Phys.Chem. - 1916. - Vol. 92. - P. 129-168. 
22. Злобин А.А., Юшков И.Р. Изучение структуры нефтяных дисперсных систем // Проблемы комплексного освоения месторождений полезных ископаемых в Пермском крае: сб. материалов краевой научн.-техн. конф. Пермь: Изд-во Перм. гос. техн. ун-та, 2007. - С. 32-41.

23. Сергиенко С.Р., Таимова Б.А., Талалаев Е.И. Высокомолекулярные неуглеводородные соединения нефти. - М.: Наука, 1979. - 270 с.

24. Федер Е. Фракталы: пер. с англ. - М.: Мир, 1991. $-260 \mathrm{c}$.

25. Смирнов Б.М. Фрактальные кластеры // Успехи физических наук. - 1986. - Т. 149, № 2. - С. 178-219.

26. Структурная организация нефтяных дисперсных систем / И.З. Мухаметзянов, И.Р. Кузеев, В.Г. Воронов, С.И. Спивак // Доклады Академии наук. - 2002. - Т. 387, № 3. - С. 353-356.

27. Мухаметзянов И.З. О применимости моделей фрактального роста к описанию структурообразования в нефтяных дисперсных системах // Коллоидный журнал. - 1991. - Т. 53, № 3. - С. 503-508.

28. Унгер Ф.Г., Андреева Л.Н. Фундаментальные аспекты химии нефти. Природа смол и асфальтенов. Новосибирск: Наука. Сибирская издательская фирма РАН, 1995. - 192 c.

29. Ролдугин В.И. Свойства фрактальных дисперсных систем // Успехи химии. - 2003. - Т. 72, вып. 11. C. $1027-1054$.

30. Смирнов Б.М. Физика фрактальных кластеров. М.: Наука, 1991. - 136 с.

31. Булавин Л.А., Выгорницкий Н.В., Лебовка Н.И. Компьютерное моделирование физических систем: учеб. пособие. - Долгопрудный: Интеллект, 2011. - 352 с.
32. Евдокимов И.Н., Елисеев Н.Ю. Особенности вязкого течения жидких сред со смолисто-асфальтеновыми веществами // Химическая технология топлив и масел. - 1999. - № 6. - С. 32-34.

33. Лесин В.И., Лесин С.В. Фрактальная формула зависимости вязкости неньютоновской жидкости от градиента скорости // Нефтяное хозяйство. - 2012. № 3. - C. 46-48.

34. Gmachowski L. Hydrodynamics of aggregated media // Journal of Colloid and Interface Science. - 1996. Vol. 178, iss. 1. - P. 80-86. DOI: 10.1006/jcis.1996.0095

35. Персиянцев М.Н. Добыча нефти в осложненных условиях. - М.: Недра-Бизнесцентр, 2000. - 653 с.

36. Мазепа Б.А. Защита нефтепромыслового оборудования от парафиновых отложений. - М.: Недра, 1972. - 120 с.

37. Тронов В.П. Механизм образования смолопарафиновых отложений и борьба с ними. - М.: Недра, 1970. - 192 c.

38. Глущенко В.Н., Силин М.А., Герин Ю.Г. Нефтепромысловая химия. T. V. Предупреждение и устранение асфальтеносмолопарафиновых отложений. М.: Интерконтакт-Наука, 2009. - 475 с.

39. Гуськова И.А., Тронов В.П., Гильманова Д.Р. Формирование асфальтосмолопарафиновых отложений в различных технологических элементах нефтедобывающей системы // Нефтяное хозяйствово. - 2008. № 3. - С. 86-87.

40. Злобин А.А., Мордвинов В.А., Юшков И.Р. Энергия активации углеводородов нефти как критерий выбора ингибиторов парафиновых отложений // Нефть, газ и бизнес. - 2011. - № 9. - С. 50-54.

Please cite this article in English as:

Zlobin A.A. Effect of fractal dimension of asphalten aggregates on macro properties of native oil. Perm Journal of Petroleum and Mining Engineering, 2018, vol.17, no.2, pp.136-151. DOI: 10.15593/2224-9923/2018.2.4

Просьба ссылаться на эту статью в русскоязычных источниках следующим образом:

Злобин А.А. Влияние фрактальной размерности асфальтеновых агрегатов на макросвойства нативной нефти // Вестник Пермского национального исследовательского политехнического университета. Геология. Нефтегазовое и горное дело. - 2018. - Т.17, №2. - С.136-151. DOI: 10.15593/2224-9923/2018.2.4 